\title{
Bone Marrow Blood-Forming Cell
}

National Cancer Institute

\section{Source}

National Cancer Institute. Bone Marrow Blood-Forming Cell. NCI Thesaurus. Code C12550

A hematopoietic stem cell found in the bone marrow. 